\title{
Corrosion of galvanic pairs of dental alloys copper base with silver amalgams in artificial saliva
}

\author{
Corrosión de pares galvánicos de \\ aleaciones dentales base cobre \\ con amalgamas de plata en \\ saliva artificial
}

Elvar Quezada-Castillo ${ }^{1}$, Wilder Aguilar-Castro ${ }^{1}$, Bertha Quezada-Alván²

\footnotetext{
${ }^{1}$ Laboratory of Physics of Materials "Lennart Hasselgren", Dept. Academic of Physics. National University of Trujillo, Trujillo, La Libertad, Peru.

${ }^{2}$ Private University Antenor Orrego, Peru. Science Department., Trujillo, La Libertad, Peru. e-mail: elvarq@yahoo.es, wilderag@yahoo.com quezada_b@yahoo.es
}

\begin{abstract}
Galvanic corrosion is a metal dissolution process that occurs when two metals of different electrochemical potential are immersed in an electrolyte causing electrical currents between the metals through the conducting medium. To restore lost or damaged teeth, different alloys are used, leaving the mouth exposed to electrical currents that circulate through saliva and dental fluids. In the present work, the potentials and densities of corrosion currents of galvanic pairs of silver amalgams and copper base dental alloys were determined simultaneously using potenciodynamic methods, finding that the most resistant to corrosion are the pairs formed by silver amalgams of high copper and $\mathrm{Cu}-\mathrm{Zn}$ alloys, and that the corrosion products released in greater quantity in the electrolytic medium are formed by $\mathrm{Hg}, \mathrm{Cu}, \mathrm{Zn}$ and $\mathrm{Ni}$ ions.
\end{abstract}

Keywords. Corrosion, dental alloy, polarization curve, artificial saliva, galvanic pair.

\section{RESUMEN}

La corrosión galvánica es un proceso de disolución metálica que se produce cuando dos metales de distinto potencial electroquímico se sumergen en un electrolito originando corrientes eléctricas entre los metales a través del medio conductor. Para restaurar las piezas dentales perdidas o deterioradas se usan diferentes aleaciones quedando la boca expuesta a corrientes eléctricas que circulan a través de la saliva y los fluidos dentarios. En el presente trabajo se determinaron simultáneamente, los potenciales y densidades de corrien-tes de corrosión de pares galvánicos de amalgamas de plata y aleaciones dentales base cobre usando méto-dos potenciodinámicos, encontrando que los más resistentes a la corrosión son los pares formados por amalgamas de plata de alto cobre y aleaciones $\mathrm{Cu}-\mathrm{Zn}$, y que los productos de corrosión liberados en ma-yor cantidad en el medio electrolítico están formados por iones $\mathrm{Hg}, \mathrm{Cu}, \mathrm{Zn}$ y Ni.

Palabras clave: Corrosión, aleación dental, curva de polarización, saliva artificial, par galvánico.

\section{INTRODUCTION}

The dental alloys have application in the restoration and correction of lost or misaligned dental pieces to preserve the correct masticatory function and the aesthetic aspect. The designs of these prostheses can take various forms and all branches of dentistry such as restorative, orthodontic, endodontic, implantology, periodontics and geriatrics apply these models $[1,2]$.

Alloys are used for direct fillings (amalgams), crowns, bridges, inlays, partial or total prostheses, fixed or mobile, implanted structures, or in the form of wires to correct defects in mastication using orthodontic appliances. These alloys are usually as cast, but in certain applications welding or bonding with porcelain or special polymers is required.

To fulfill these functions the alloys must meet a variety of biocompatibility requirements, suitable 
physical properties, wear resistance or corrosion resistance and acceptable and stable appearance. The most traditional are noble alloys containing not less than $75 \%$ gold and platinum group metals. The techniques of casting, cast and finished are simple and do not suffer deterioration of their properties over time or lose their aesthetic appearance. In contrast, they have the disadvantage of having high density, under elastic modulus and are too expensive [3].

For this reason, alloys of non-precious metals have been developed to replace high gold alloys, which have been used since the 1940s in developed countries. Among these we have the ones of $\mathrm{Co}-\mathrm{Cr}, \mathrm{Ni}-\mathrm{Cr}$ and lately those of base titanium. In developing countries such as ours copper base alloys are used: $\mathrm{Cu}-\mathrm{Al}$, $\mathrm{Cu}-\mathrm{Zn}$ and $\mathrm{Cu}-\mathrm{Ni}$ and amalgams of silver of low and high copper by its reduced cost, as has been mentioned in foreign publications [4] and manifested in presentations made by various researchers at the meetings of the Argentine Branch of the International Association for Dental Research [5-7].

Two or more dissimilar metals in the mouth form batteries that generate galvanic currents, due to electrolytic contact through the saliva or the root fluids; these pairs interact by direct, indirect or intermittent contact [1]. Research has been carried out on galvanic pairs of alloys of $\mathrm{Au}, \mathrm{Co}-\mathrm{Cr}, \mathrm{Ni}-\mathrm{Cr}$, titanium and stainless steel with amalgams [8-13]. In this work we will study the susceptibility to corrosion of galvanic pairs of copper base alloys $(\mathrm{Cu}-\mathrm{Al}, \mathrm{Cu}-\mathrm{Zn}$, and $\mathrm{Cu}-\mathrm{Ni})$ with silver amalgams using potenciodynamic methods and later determine the corrosion products by EDAX and SEM.

\section{MATERIALS AND METHODS}

\subsection{Materials}

Three copper base dental alloys and two silver amalgams whose chemical composition are shown in table 1 have been used.

Table 1: Chemical composition of amalgams and dental alloys base copper by weight $\%$.

\begin{tabular}{|c|c|c|c|}
\hline ALLOYS & TRADENAME & CODE & CHEMICAL COMPOSITION \\
\hline Dental Mercury & UnoDent & & Hg 99.99 \\
\hline \multirow{2}{*}{ Silver Amalgams } & Low-copper dental amalgam Standalloy F & 1 & Ag $71.0-$ Sn $25.7-\mathrm{Cu} 3.3$ \\
\hline & High-copper dental amalgam Duralloy S & 2 & $\mathrm{Ag} 45-\mathrm{Sn} 31-\mathrm{Cu} 24$ \\
\hline $\mathrm{Cu}-\mathrm{Ni}$ alloy & Aurocast & 3 & $\mathrm{Cu} 57.9$ - Ni $22.1-\mathrm{Al} 15.0$ - Fe 5.0 \\
\hline $\mathrm{Cu}-\mathrm{Zn}$ alloy & Orodent & 4 & $\mathrm{Cu} 53.9-\mathrm{Zn} 45.9-\mathrm{Fe} 0.05-\mathrm{Ni} 0.02$ \\
\hline $\mathrm{Cu}-\mathrm{Al}$ alloy & Pentacast & 5 & $\mathrm{Cu} 77.9$ - Al 12.0 - Ni 5.1 - Fe 5.0 \\
\hline
\end{tabular}

\subsection{Preparation of test pieces}

- The copper base samples were prepared by the lost wax method with an oxygen - butane - propane flame and centrifugation processes.

- The amalgams were crushed and condensed according to the manufacturer's instructions [14]. In both cases the specimens were cylinders $0.5 \mathrm{~cm}$ high and $0.8 \mathrm{~cm}$ in diameter.

\subsection{Electrochemical methods}

To predict the corrosion of galvanic pairs in electrolytic solutions, measurements of potential, polarization and current must be made [15].

- Potential measurements - The electrode potential of each alloy was measured with a saturated calomel electrode in a three-electrode cell and a Princeton Applied Research Potenciostat Model 173. Prior to the measurement, the specimen was introduced to the solution and at the same time air was circulated at a rate of 80 bubbles per minute with a fish tank aerator. Before measuring the corrosion 
potential, it was waited 30 minutes for the potential to stabilize always under the action of the air stream. Potentials were measured five times with different specimens.

- Polarization curves - The potentiodynamic polarization curves were plotted in triplicate using the same cell and the same potentiostat as the one used to measure the electrode potential. The reference electrode was saturated calomel and the platinum counter electrode. The scanning speed was $12 \mathrm{mV}$ / min and the curves were recorded with an XT Princeton Applied Reserch Model REO 151 plotter. Before plotting the curves the corrosion potential was measured in the same manner as in the previous section. The global curves (anodic and cathodic) of each alloy were drawn with different specimens. Once the tests were finished, the specimens were analyzed with a scanning electron microscope to determine the corrosion products by EDAX.

- Potential corrosion of galvanic pairs - Dental alloys are corroded in the oral environment by the action of saliva and bone fluids so that when electrically coupled both are polarized and corrode at a new speed. When the metals A and B of equal areas are coupled, the mixed potential and the current density (Ecupla and Icupla) of the galvanic cupla are at the intersection of the anodic curves of the less noble metal (A) and cathodic of the metal plus noble (B) [16].

- Electrolyte - The electrolyte used in electrochemical tests is an experimental saliva that reproduces the electrochemical behavior of natural saliva [17], whose formula is shown in Table 2. The electrolyte was prepared with deionized water of $18.2 \mathrm{M} \Omega$-cm electrical resistivity and with reagents of analytical grade. The $\mathrm{pH}$ of the solution was 6.5; to prevent this value from being modified, KHCO3 must be added shortly before starting the tests.

Table 2: Chemical composition of experimental saliva [17].

\begin{tabular}{l|c}
\hline \multicolumn{1}{c|}{ REAGENT } & CONCENTRATION (g/L) \\
\hline $\mathrm{NaCl}$ & 0.600 \\
\hline $\mathrm{KCl}$ & 0.720 \\
\hline $\mathrm{CaCl}_{2} .2 \mathrm{H}_{2} \mathrm{O}$ & 0.220 \\
\hline $\mathrm{KH}_{2} \mathrm{PO}_{4}$ & 0.680 \\
\hline $\mathrm{Na}_{2} \mathrm{HPO}_{4} .12 \mathrm{H}_{2} \mathrm{O}$ & 0.856 \\
\hline $\mathrm{KSCN}$ & 0.060 \\
\hline $\mathrm{KHCO}_{3}$ & 1.500 \\
\hline $\mathrm{H}_{8} \mathrm{C}_{6} \mathrm{O}_{7}$ (cítric acid) & 0.030 \\
\hline
\end{tabular}

\section{RESULTS AND DISCUSSION}

\subsection{Electrochemical series}

Table 3 shows the average open circuit corrosion potentials of the studied alloys according to their resistance to corrosion. The average standard deviation calculated according to G standard: 16-95 ASTM [18] is also shown. Copper base alloys manufactured to substitute gold for their yellow color have high potential for corrosion due to the large amount of copper they contain. In contrast, the Standalloy F amalgam has a low corrosion potential due to the small amount of copper it contains compared to the other alloys considered in this work. 
Table 3: Corrosion Potentials and Average Standard Deviations.

\begin{tabular}{l|c|c}
\hline \multicolumn{1}{c|}{ ALLOY } & $\mathrm{V}_{\text {corr }}\left(\mathrm{mV}_{\text {sce }}\right)$ & $\sigma\left(\mathrm{mV}_{\text {sce }}\right)$ \\
\hline $\begin{array}{l}\text { Copper high amalgam } \\
\text { (Duralloy S) }\end{array}$ & -230 & 12 \\
\hline Orodent & -233 & 12 \\
\hline Aurocast & -252 & 5 \\
\hline Pentacast & -260 & 7 \\
\hline $\begin{array}{l}\text { Copper under amalgam } \\
\text { Standalloy F) }\end{array}$ & -381 & 18 \\
\hline
\end{tabular}

\subsection{Polarization curves}

Dental amalgams are galvanically corroded in the mouth due to the different phases that have: $\mathrm{Ag}-\mathrm{Hg}, \mathrm{Ag}-\mathrm{Sn}$ and $\mathrm{Sn}-\mathrm{Hg}$, each of which has a different electrochemical potential due to its diverse chemical composition $[19,20]$

Figure 1 shows the overall polarization curves of the alloys under study. The cathodic curves of these alloys are similar; for small over cathodic potential the current density increases rapidly observing a linear relationship between the potential envelope and the logarithm of the current. In all cases the cathodic region corresponds to the evolution of hydrogen [21].

The low copper amalgam (Standalloy F) has a passive zone that extends from $-370 \mathrm{mV}_{\text {sce }}$ to -100 $\mathrm{mV}_{\text {sce }}$ and its breaking potential is $-90 \mathrm{mV}_{\text {sce }}$, from this value the current density increases rapidly. The amalgam of high copper (Duralloy S), not represented in all its extension, have a current density of $2.20 \mu \mathrm{A} / \mathrm{cm}^{2}$ at the height of the rupture potentials of aurocast and pentacast. The current density of the Standalloy passive zone is $0.30 \mu \mathrm{A} / \mathrm{cm}^{2}$ obtained by averaging the current densities of its passive zone.

The most corrosive phase of the low copper amalgam is the $\gamma_{2}$ or Sn-Hg phase, due to the formation of tin oxychloride from the tin of the $\gamma_{2}$ phase and also the release of mercury [19]. The high copper quality amalgams do not have phase $\gamma_{2}$ and the most corrosion resistant phase of these alloys is the $\mathrm{Ag}-\mathrm{Hg}$ phase [22].

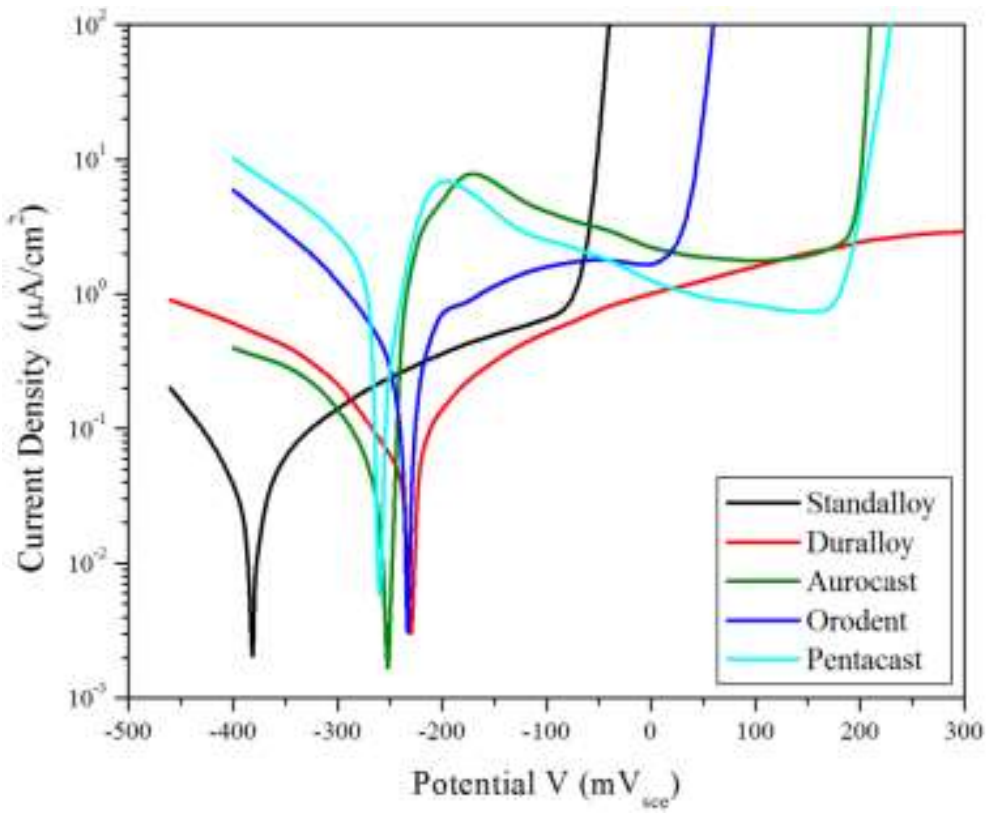

Figure 1. Polarization curves of silver amalgams and copper base alloys. 
The $\mathrm{Cu}-\mathrm{Al}$ alloy presents a passive zone that extends from - $190 \mathrm{mV}_{\text {sce }}$ to $180 \mathrm{mV}_{\text {sce }}$ with an average current density in this area of $2 \mu \mathrm{A} / \mathrm{cm}^{2}$. Its breaking potential is $200 \mathrm{mV}_{\text {sce }}$, from which dissolution of the interdendritic structure of the alloy known as phase k occurs, formed by segregation of $\mathrm{Fe}$ and $\mathrm{Ni}$ due to its insolubility in the $\alpha$ phase [23]. The $\mathrm{Cu}-\mathrm{Ni}$ alloy has a passive zone extending from $-160 \mathrm{mV}_{\text {sce }}$ to $200 \mathrm{mV}_{\text {sce }}$

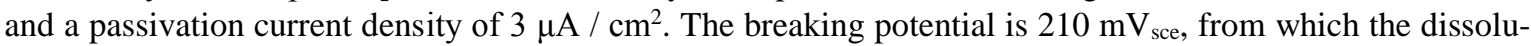
tion of the material takes place. The $\mathrm{Cu}-\mathrm{Zn}$ alloy has a small passive zone that extends from $-180 \mathrm{mV}_{\text {sce }} \mathrm{up}$ to $20 \mathrm{mV}_{\text {sce }}$ and a passive current density of $1.50 \mu \mathrm{A} / \mathrm{cm}^{2}$. The reduction of this zone compared to the previous alloys is due to its high $\mathrm{Zn}$ content[1]. From the rupture potentials the current densities of the copper base alloys rapidly increase to small over potentials as shown in figure 1, due to the selective dissolution of the material known as dealloyed.

\subsection{Potentials and densities of corrosion current of galvanic pairs}

The potential and corrosion current densities of the galvanic pairs under study are determined from the intersection of the cathodic curves of the silver amalgams and the anodic curves of the copper base alloys, as shown in figure 2 . The results are presented in table 4.

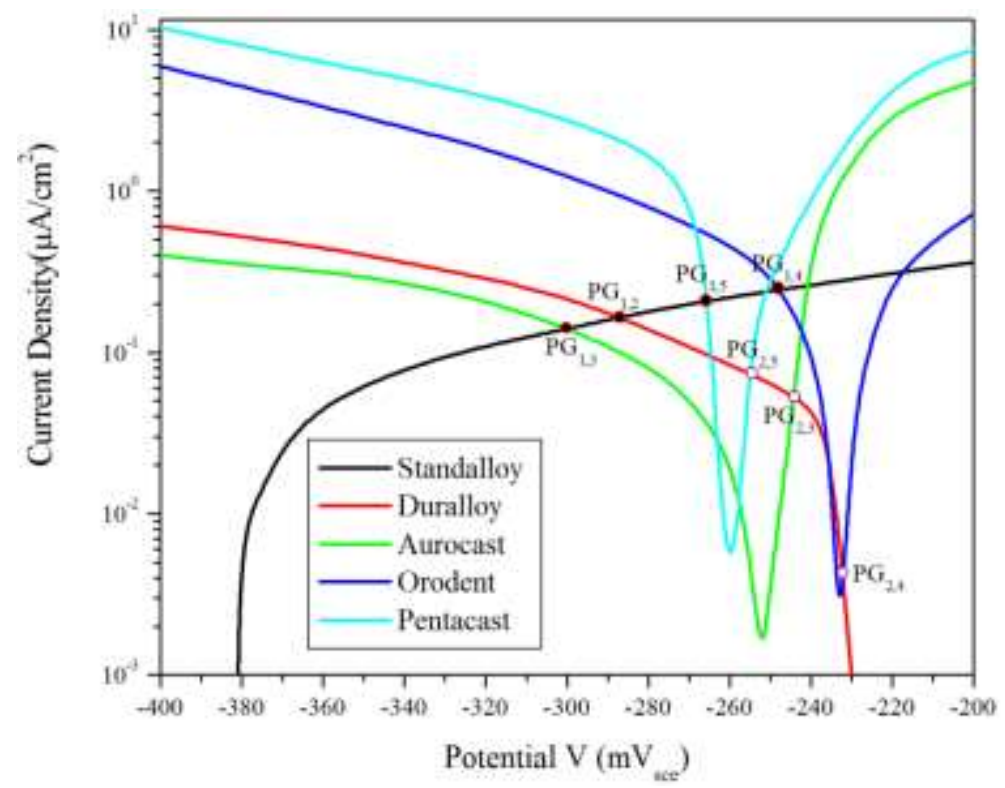

Figure 2: Intersection of anodic curve of Standalloy and cathodic of Duralloy with the anodic and cathodic curves of copper base dental alloys.

Table 4: Potentials and corrosion current densities of galvanic pairs of copper base dental alloys with silver amalgam.

\begin{tabular}{l|c|c}
\hline GALVANIC COUPLES NOTATION & $\mathrm{V}_{\text {corr.cupla }}\left(\mathrm{mV}_{\text {sce }}\right)$ & $\mathrm{I}_{\text {corr.cupla }}\left(\mu \mathrm{A} / \mathrm{cm}^{2}\right)$ \\
\hline Standalloy/Duralloy $\left(\mathrm{PG}_{1,2}\right)$ & -287 & 0.165 \\
\hline Standalloy/Aurocast $\left(\mathrm{PG}_{1,3}\right)$ & -299 & 0.142 \\
\hline Standalloy/Orodent $\left(\mathrm{PG}_{1,4}\right)$ & -247 & 0.244 \\
\hline Standalloy/Pentacast $\left(\mathrm{PG}_{1,5}\right)$ & -264 & 0.216 \\
\hline Duralloy/Aurocast $\left(\mathrm{PG}_{2,3}\right)$ & -244 & $0.055^{*}$ \\
\hline Duralloy/Orodent $\left(\mathrm{PG}_{2,4}\right)$ & -232 & $0.004^{*}$ \\
\hline Duralloy/Pentacast $\left(\mathrm{PG}_{2,5}\right)$ & -255 & $0.008^{*}$ \\
\hline
\end{tabular}

\footnotetext{
* indicates that the copper base alloy is corroded.
} 
In Table 4 we observe that the range of the corrosion potentials of the galvanic pairs of the alloys under study with Standalloy is between - $299 \mathrm{mV}_{\text {sce }}$ and $-247 \mathrm{mV}_{\text {sce }}$ and the current densities between $0.244 \mu \mathrm{A}$ $/ \mathrm{cm}^{2}$ and $0.142 \mu \mathrm{A} / \mathrm{cm}^{2}$. For Duralloy-formed pairs the corrosion potentials are between $-255 \mathrm{mV}_{\text {sce }}$ and $-232 \mathrm{mV}_{\text {sce }}$ and the current densities between $0.055 \mu \mathrm{A} / \mathrm{cm}^{2}$ and $0.004 \mu \mathrm{A} / \mathrm{cm}^{2}$.

\subsection{Corrosion products of galvanic pairs}

At the end of the tests the corrosion products were observed with a scanning electron microscope (Phillips 500) and by making a general sweep of the surface of the specimens by EDAX the corrosion products whose spectra are shown in figures 3 to 7 were qualitatively determined.

Figures 3 and 4 show the SEM micrographs of the corrosion products and the EDAX spectra of the silver amalgam of low and high copper with high peaks of $\mathrm{Hg}, \mathrm{Sn}, \mathrm{Ag}, \mathrm{Cl}$ and $\mathrm{Cu}$ and small peaks of $\mathrm{P}, \mathrm{Si}$ and $\mathrm{Ca}$. in agreement with the results of other researchers [24,25]. Since this technique does not register oxygen or hydrogen, it is assumed that oxides, hydroxides, phosphates and chlorides are formed from these elements, such as those identified by Fathi and Mortazavi in dental patients [19].

Figures 5 to 7 show the SEM micrographs of the corrosion products and the EDAX spectra of the $\mathrm{Cu}$ base alloys, showing high peaks of $\mathrm{Cu}$ and $\mathrm{Zn}$ and small peaks of $\mathrm{Al}, \mathrm{Ni}$ and Fe. The analysis of the spectra and the bibliographic references [26,27], indicate that oxides, hydroxides, phosphates and copper chlorides are formed, mainly, and aluminum, iron and nickel, in a minority form.

The ions released in corrosion processes can be stored in the mucosa in the form of staining or pass through the digestive tract to the stomach. Some of them are eliminated abroad and the rest is stored in some organ such as liver, kidneys, lungs or brain [28].

$\mathrm{Cu}$ ions are released when copper amalgams and dental alloys dissolve and are stored in the gingival tissue adjacent to the restored tooth. These ions affect the viability and proliferation of lymphocytes. Over time the concentration of copper increases in the gums, producing inflammation, alteration of cellular immunity and oral homeostasis. In general, these ions contribute to a variety of immunopathological conditions including periodontal diseases and decreased resistance to oral infections [29].
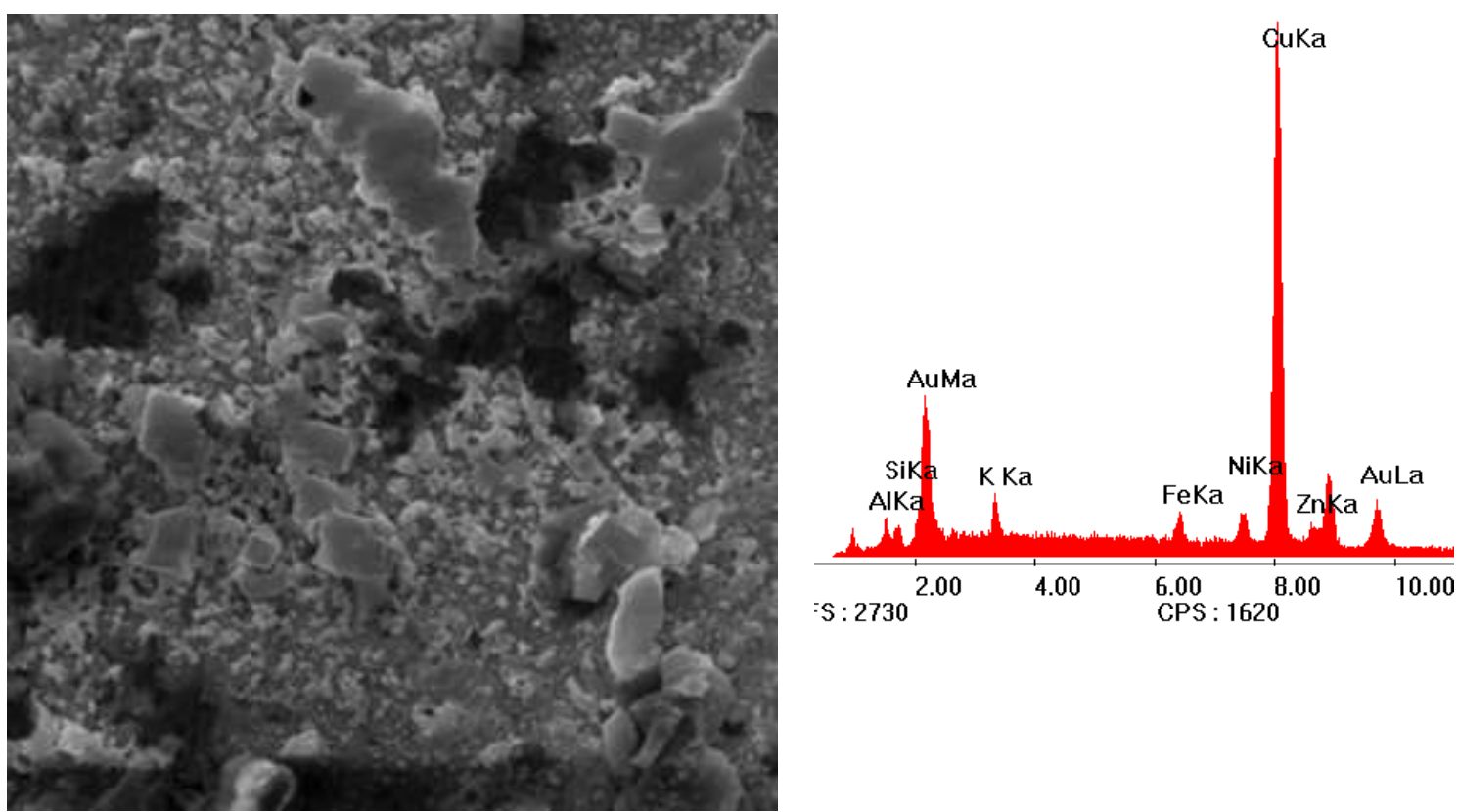

Figure 3: SEM micrograph and EDAX spectra of corrosion products on Standalloy $(\times 1440)$. 

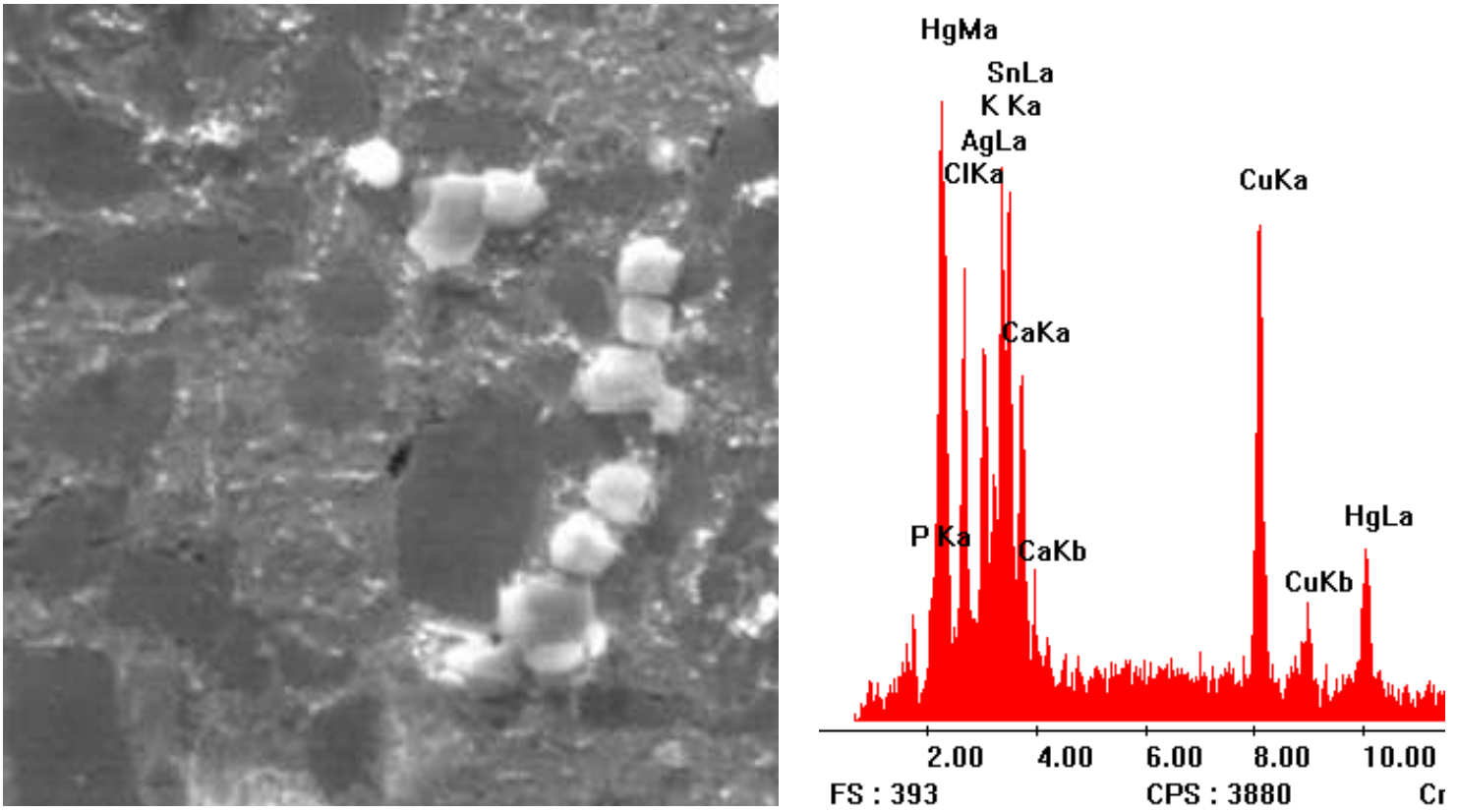

Figure 4: SEM micrograph and EDAX spectra of corrosion products on Duralloy $(\times 1280)$.
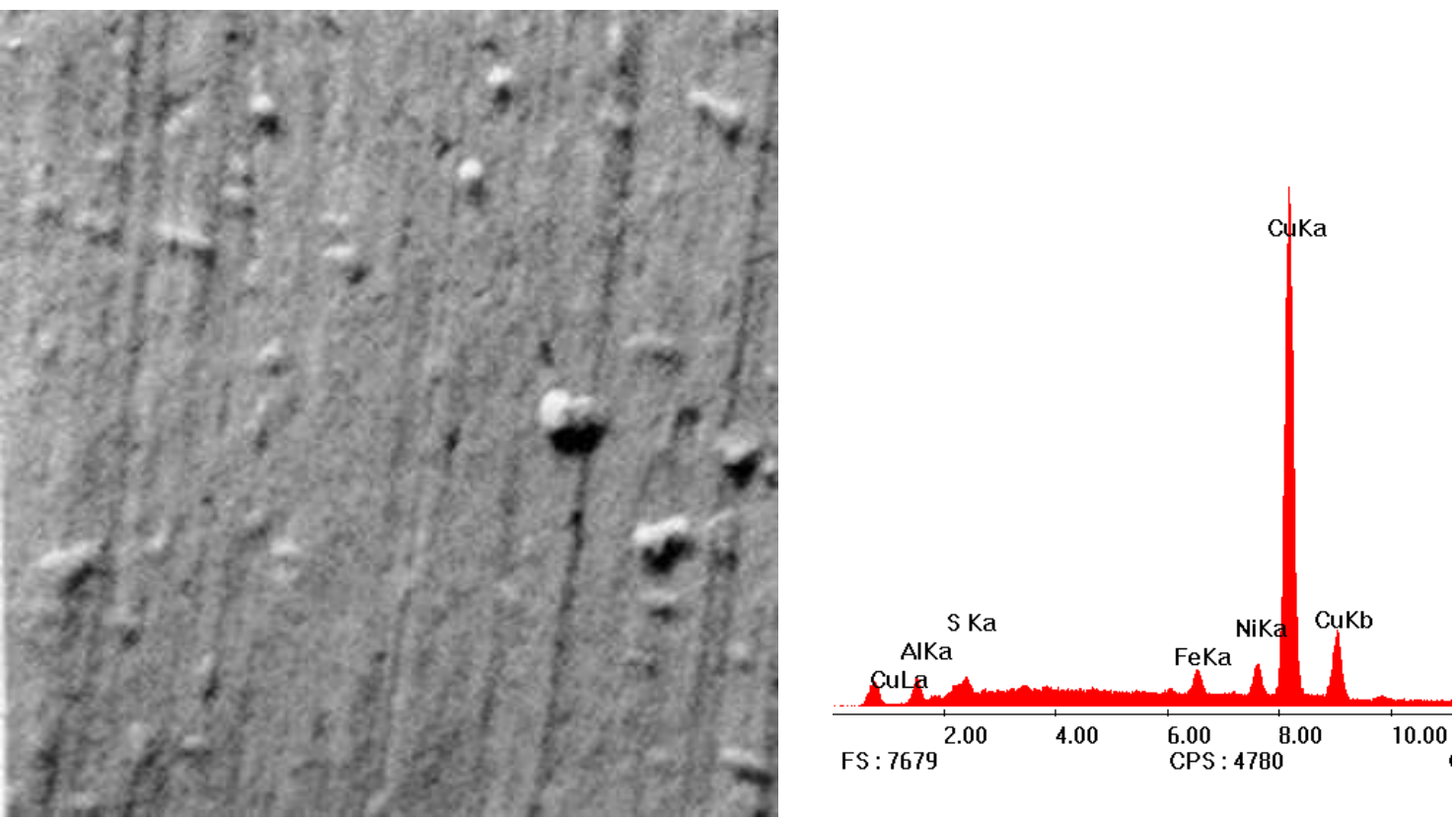

Figure 5: SEM micrograph and EDAX spectra of corrosion products on Pentacast $(\times 1440)$. 

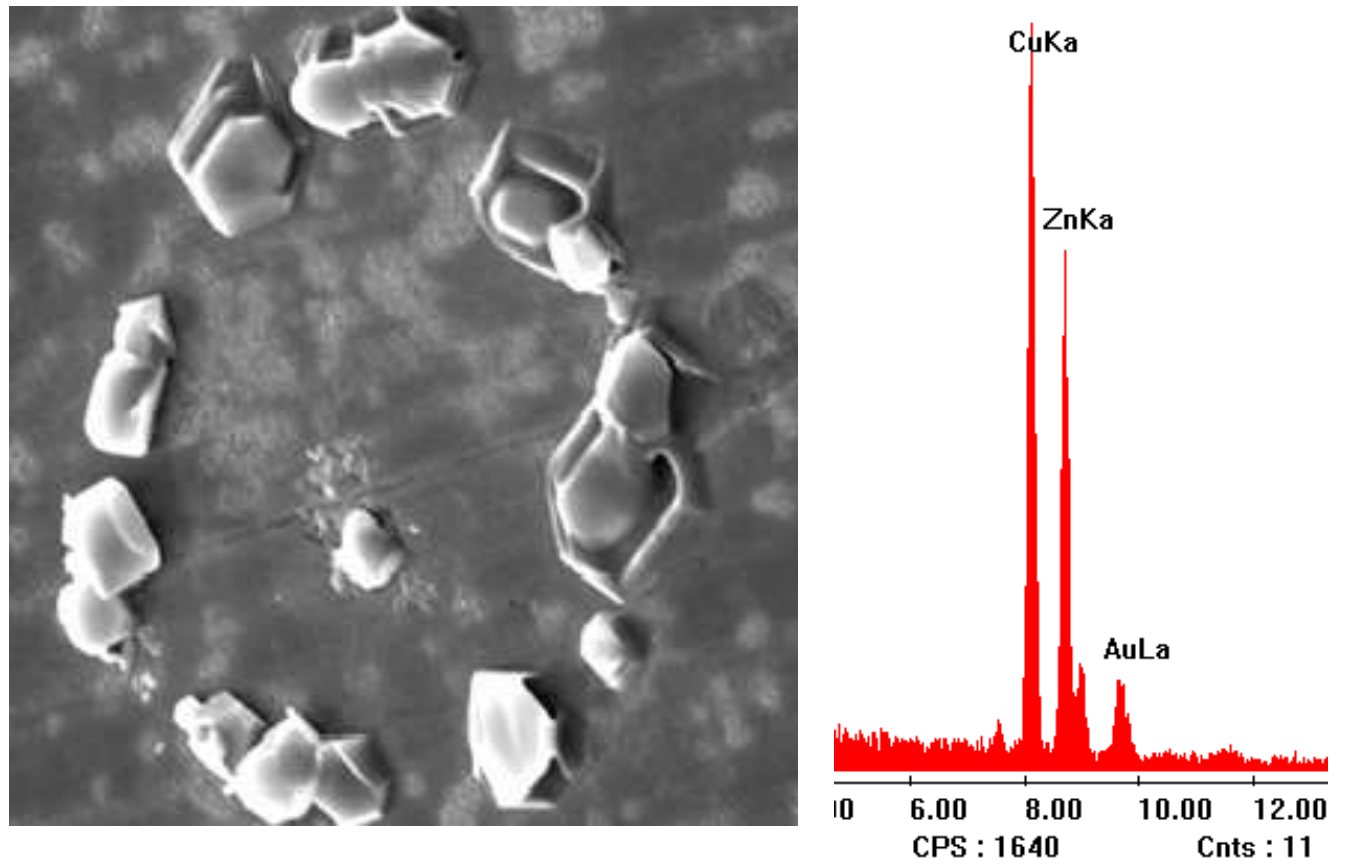

Figure 6: SEM micrograph and EDAX spectra of corrosion products on Orodent $(\times 1200)$.

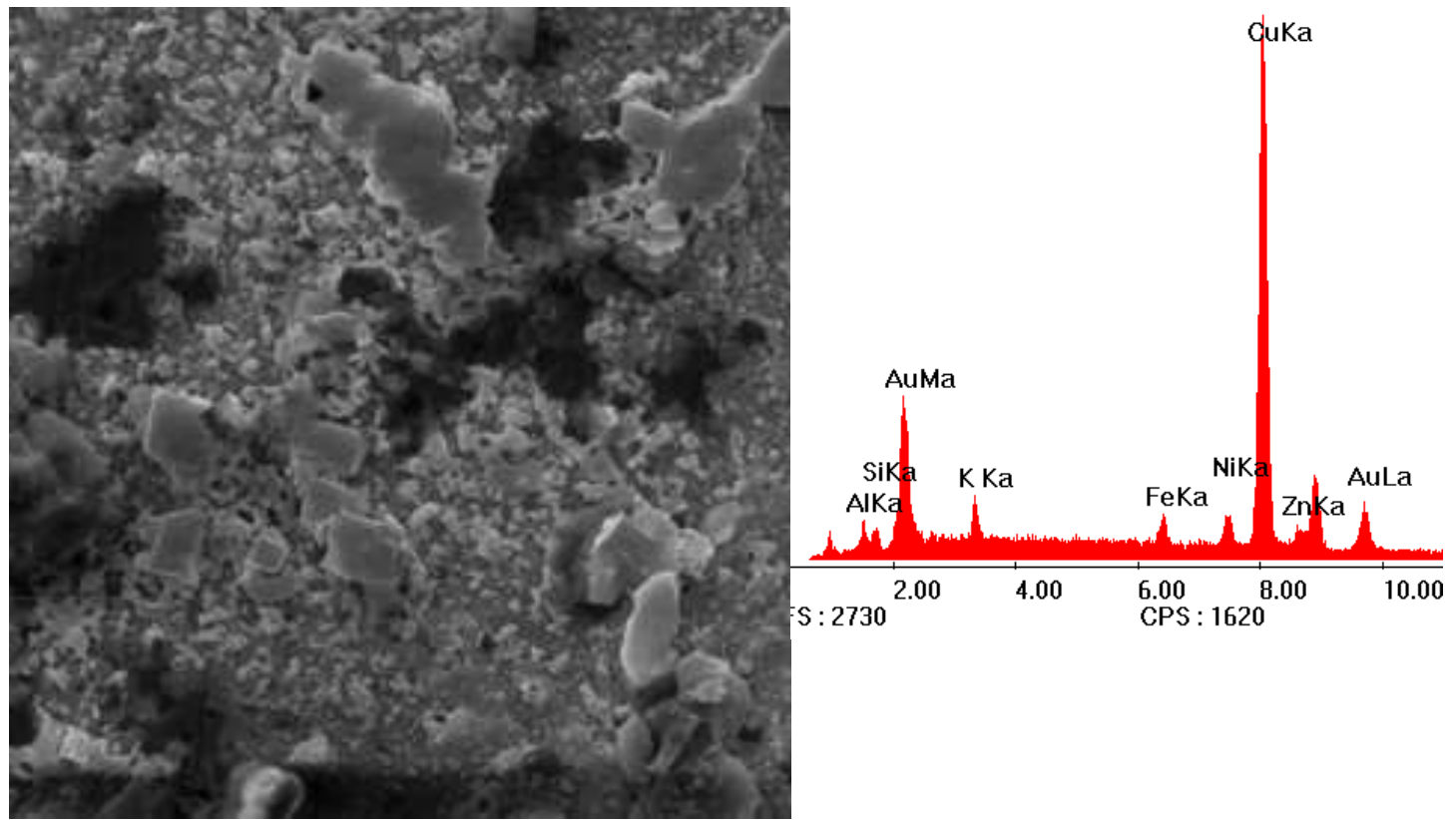

Figure 7: SEM micrograph and EDAX spectra of corrosion products on Aurocast $(\times 1120)$.

The major component mercury of amalgams is highly toxic and very permeable through the cell membrane, being able to pass from the gastrointestinal tract to the lungs and brain. It has been found "mercury in the hairs, nails and a high concentration in the pituitary gland (approximately 70 times higher than in the control groups) in people who have amalgams in the mouth" [29]. Nickel is a potential allergic, and is the most common cause of allergic contact dermatitis, it is present in most jewelry and household utensils. Therefore, it can be considered a danger to public health increasing with the use of dental restorations. Ni ions produce nonspecific allergies and inflammations around restorations that can take lichenoid and sometimes erosive 
reactions, with women being more hypersensitive to this metal because of the jewelry that they use from an early age $[30,31]$.

\section{CONCLUSIONS}

From the results obtained in the present work it can be established that:

1. Galvanic pairs of copper base dental alloys with high copper silver amalgams are more resistant to corrosion than pairs formed with low copper silver amalgams. The most resistant pair is $\mathrm{PG}_{2,4}$ (Duralloy / Orodent) and the less resistant the pair $\mathrm{PG}_{1,5}$ (Standalloy / Pentacast).

2. All dental alloys release ions into the oral environment. Some of these diffuse into the buccal mucosa and the rest pass into the gastrointestinal system. They are then distributed and stored in different parts of the body, such as brain, lungs, liver and kidneys affecting the health of patients, especially when the concentration of corrosion products $(\mathrm{Hg}, \mathrm{Cu}, \mathrm{Ni}$, etc.) exceeds normal tolerance limits.

\section{ACKNOWLEDGMENT}

The Materials Laboratory of the National Commission for Atomic Energy (Constituents) of the Republic Argentina, for allowing us to use their equipment in sections of Corrosion and Electron Microscopy.

\section{BIBLIOGRAPHY}

[1] MUELLER, H. J., "Tarnish and Corrosion of Dental Alloys", In Metal Handbook, v. 13, Ohio, Ed. ASM International Metal Park, pp. 1336 - 1366, 1992.

[2] PHILlIPS, R. W., La Ciencia de los Materiales Dentales, $9^{\circ}$ Edición, Cap. 16, Editorial Interamericana, México, 1988.

[3] Guide to Dental Materials and Device, American Dental Association, 7 th Ed., Chicago, 1974.

[4] NAKAYAMA, M., MOSER, J. B. AND GREENER, E.H. "Corrosion and Tarnish of Aluminum Bronze", Dent. Mater. J., v.3, pp.133, 1984.

[5] Proc. XXIII Reunión Anual de la División Argentina de la International Association for Dental Research (I.A.D.R.), Buenos Aires, 1990.

[6] Proc. XXIV Reunión Anual de la División Argentina de la International Association for Dental Research (I.A.D.R.), Villa Giordano (Córdoba), 1991.

[7] Proc. XXV Reunión Anual de la División Argentina de la International Association for Dental Research (I.A.D.R.), Paraná (Entre Ríos), 1992.

[8] HALLAND, R.I., “Galvanic currents between gold and amalgam”, Scand. J Dent Res. v.88, pp. 269-272, 1980.

[9] RAVNHOL, G., "Corrosion Current and PH rise around titanium coupled to dental alloys", Scand. J. Res. v.96, pp. 466-472, 1988.

[10] RAVNHOLT, G., JENSEN, J., "Corrosion investigation of two materials for implant supraconstructions coupled to a titanium implant”, Dent. Res. v.99, pp. 181-186, 1991.

[11] GRIFFIN, CH., BUCHANAN,R.A., LEMOUS, J.E., "In vitro electrochemical corrosion study of coupled surgical implant materials", J. of Biomedical Mat. Res. v.17, pp. 489 - 500, 1996.

[12] CISZEWSKI, A., BARANIAK, M., URBANEK-BRYCHCZYNSKA, M., "Corrosion by Galvanic Coupling Between Amalgam and Different Chromium-Based Alloys", Dental Materials, v. 23, pp. 1256 1261, Dec. 2007.

[13] CAPELO, S., PROENCA, L., FERNANDEZ, J., et al., "Galvanic Corrosion of Two Non Noble Dental Alloys", Int. J. Electrochem. Sci., v. 9, pp. 593 - 609, Sep. 2014.

[14] COIMPA - Sociedade Industrial de Metais Preciosos da Amazonia Ltda. 11. Instrucciones para uso de amalgamas, Brasil.

[15] BABOIAN, R., "Electrochemical techniques for predicting galvanic corrosion". In: BOBOIAN, R, 
FRANCE, W.D J.R, ROEW, L.C., et al., Galvanic and Pitting - field and Laboratory Studies. ASTM stp 556. Philadelphia: American Society for Testing and Materials, pp 6- 9, 1976.

[16] JONES DENNY A. Principles and Prevention of Corrosion. $2^{\circ}$ Ed. Prentice Hall, Upper Saddle Rivers, N.J., pp. 177, 1996.

[17] DUFFO,G.S., QUEZADA, E., "Development of an Artificial Saliva Solution for Studying the Corrosion Behavior of Dental Alloys”, Corrosion, v. 60, pp. 594-602, Jun. 2004.

[18] ASTM Standars: G.16-95. "Standars guide for applying statistics to analysis of corrosion dat". In, Anual Booke of ASTM Standards, v. 03, pp.02, 1999.

[19] FATHI, M., MORTAZARVI,V., "A review on Dental Amalgam Corrosion and Its Consecuences", Journal of Research in Medical Science, v. 9, n. 1, pp. 42-51, 2004.

[20] ACCIARI, H.A., GUASTALDI, A.C., BRETTT, C.M.A., Corrosion of dental amalgam: electrochemical study of Ag-Hg, Ag-Sn and Sn-Hg phases”, Electrochemica Acta, v.42, n. 1, pp.3887-3893, Jan. 2001.

[21] GONZALES FERNANDEZ, G.A., Control de la corrosión: estudio y medida por técnicas electroquímicas, $1^{a}$ Edición, Consej Superior de Investigaciones Científicas. Centro Nacional de Investigaciones Metalúrgicas, pp. 97, Madrid ,1989.

[22] BRETT, C. M. A., TRANDAFIR, F., "The corrosion of dental amalgam in artificial salivas: an electrochemical impedance study”, Journal of Electroanalytical Chemistry, v. 552, n. 1, pp. 347-354, Feb. 2004.

[23] BREZINA, P., "Heat treatment of complex aluminium bronzes”, International Metals Reviews, v.21, n.1, pp. 77-120, Jan. 1982.

[24] SARKAR, N.K., MARSHALL, G. W., MOSER J.B., et al., "In vivo and In vitro Corrosion Products of Dental Amalgam”, J Dent Res., v. 54, n. 5, pp. 1031-1038, Sep.-Oct. 1975.

[25] FINKELSTEIN, G. F., GREENER, E. H., "In vitro polarization of dental in human saliva", Journal of Oral Rehabilitation, v.04, n.4, pp.347-354, Oct. 1977.

[26] MUELER, H., "The effects of a human salivary dialysate upon ionic release and electrochemical corrosion of a Copper-Aluminim alloy”, Journal Electrochemical Society, v. 134, n. 3, pp. 575-580, Mar. 1987.

[27] SARKAR, N. K., "SEM and x-ray microanalysis of in vitro corrosion of a copper-zinc alloy", Journal of Prosthetic Dentistry, v. 45, n. 3, pp. 292-295, Mar. 1981.

[28] BRUNE, D., GJERDET, N., PAULSEN, G., "Gastrointestinal and in vitro release of copper, cadmium, indium, mercury and zinc from conventional and copper-rich amalgams", Scand. J. Dent. Res., v. 91, n. 1, pp. $66-71$, Feb. 1983.

[29] BUMGARDNER, J.D., LUCAS, L.C., ALVERSON, M.W., et al., "Effects of copper-based casting alloys on two lymphocyte cell lines and the secretion of interleukin 2 and Ig", Dent. Mater., v. 9, pp. 85 - 90, 1993.

[30] BURROWS, D. "Hypersensitivity to mercury, nickel and chromium in relation to dental materials", International Dental Journal, v. 36,n. 1, pp. 30-34, Mar. 1986.

[31] BLANCO-DALMA, L., CARRASQUILLO-ALBERT, H., SILVA PARRA, J. "A study of nickel allergy", J. Prosth Dent, v. 52, n. 1, pp. 116-119, Jul. 1984.

ORCID

Elvar Fortunato Quezada Castillo http://orcid.org/0000-0002-5851-6806

Wilder Máximo Aguilar Castro http://orcid.org/ 0000-0001-7919-2014

Bertha Elba Quezada Alvan http://orcid.org/ 0000-0003-0504-4566 